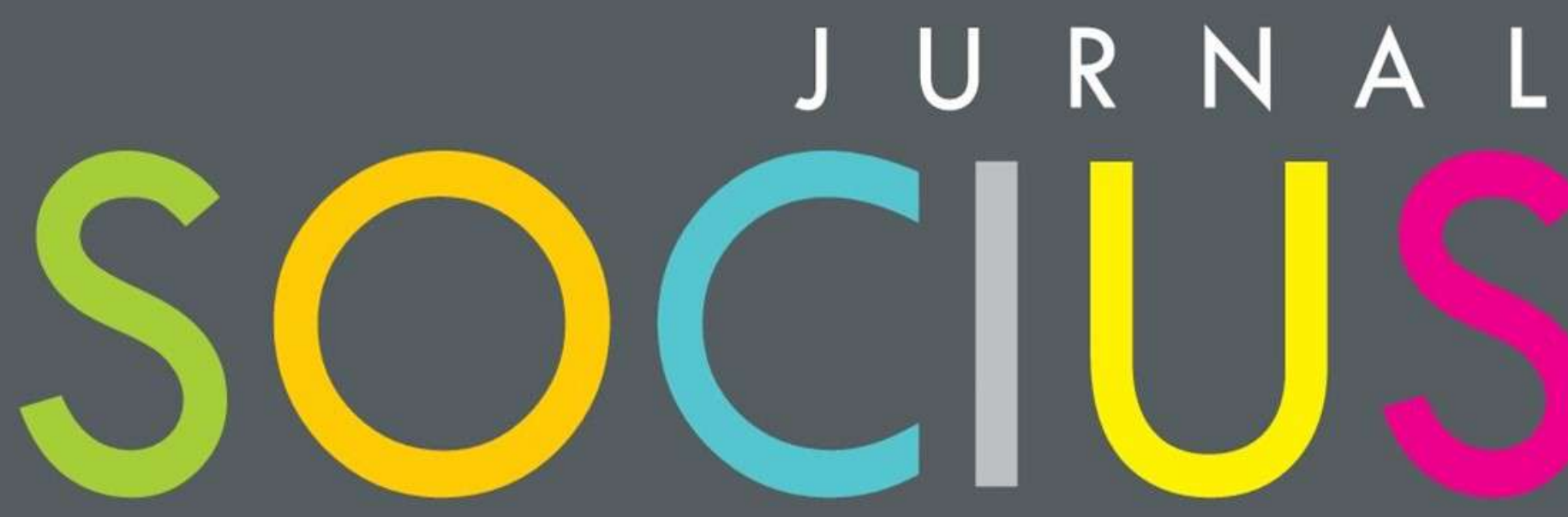

Journal of Sociology Research and Education

DITERBITKAN OLEH :

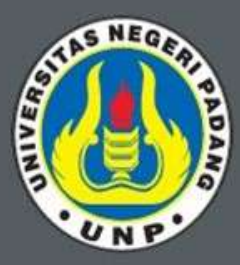

LABOR JURUSAN SOSIOLOGI FAKULTAS ILMU SOSIAL UNIVERSITAS NEGERI PADANG

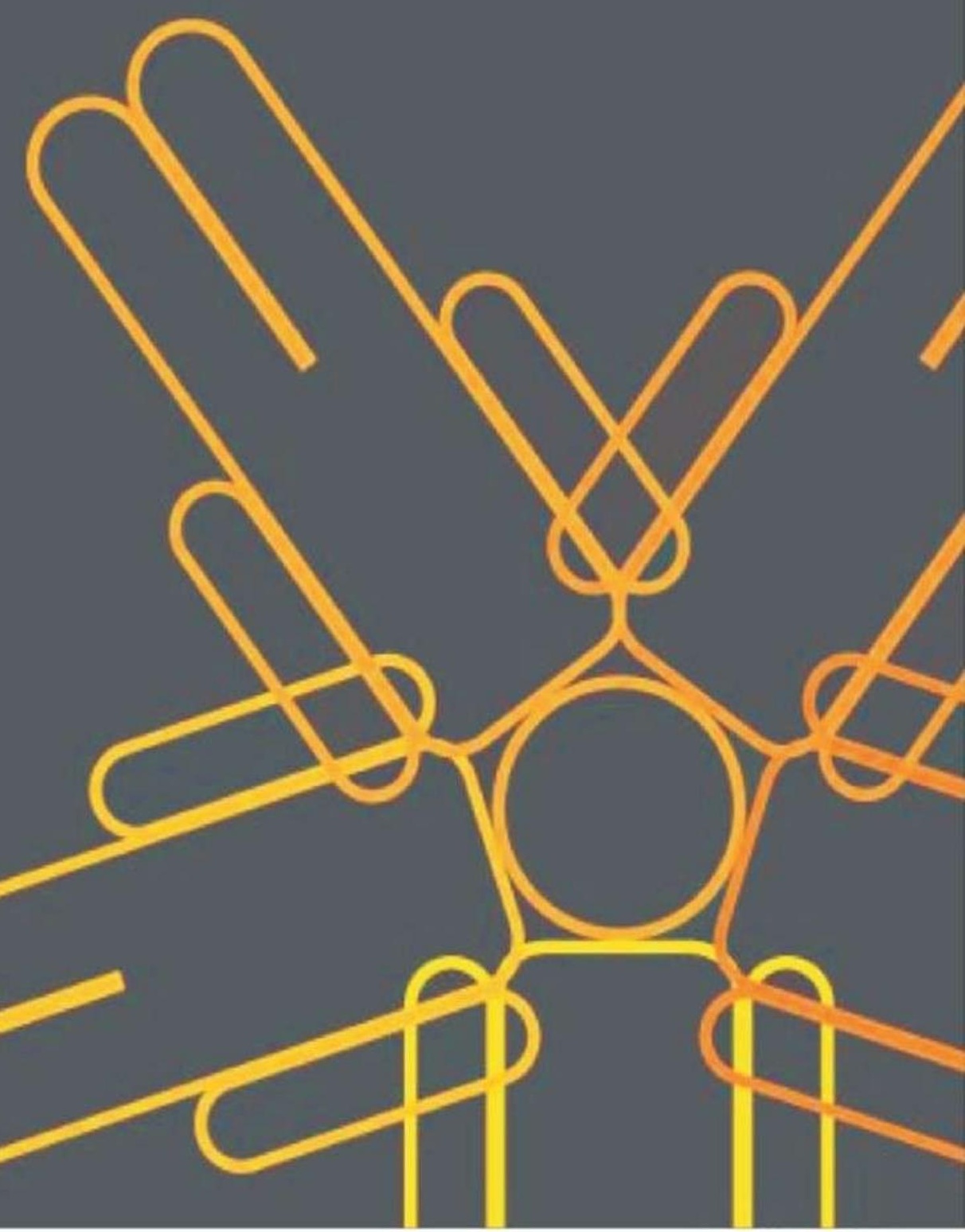




\section{SOCIUS}

Vol. 7, No. 1, Th. 2020

ISSN : 2356-4180 (cetak)

2442-8663 (online)

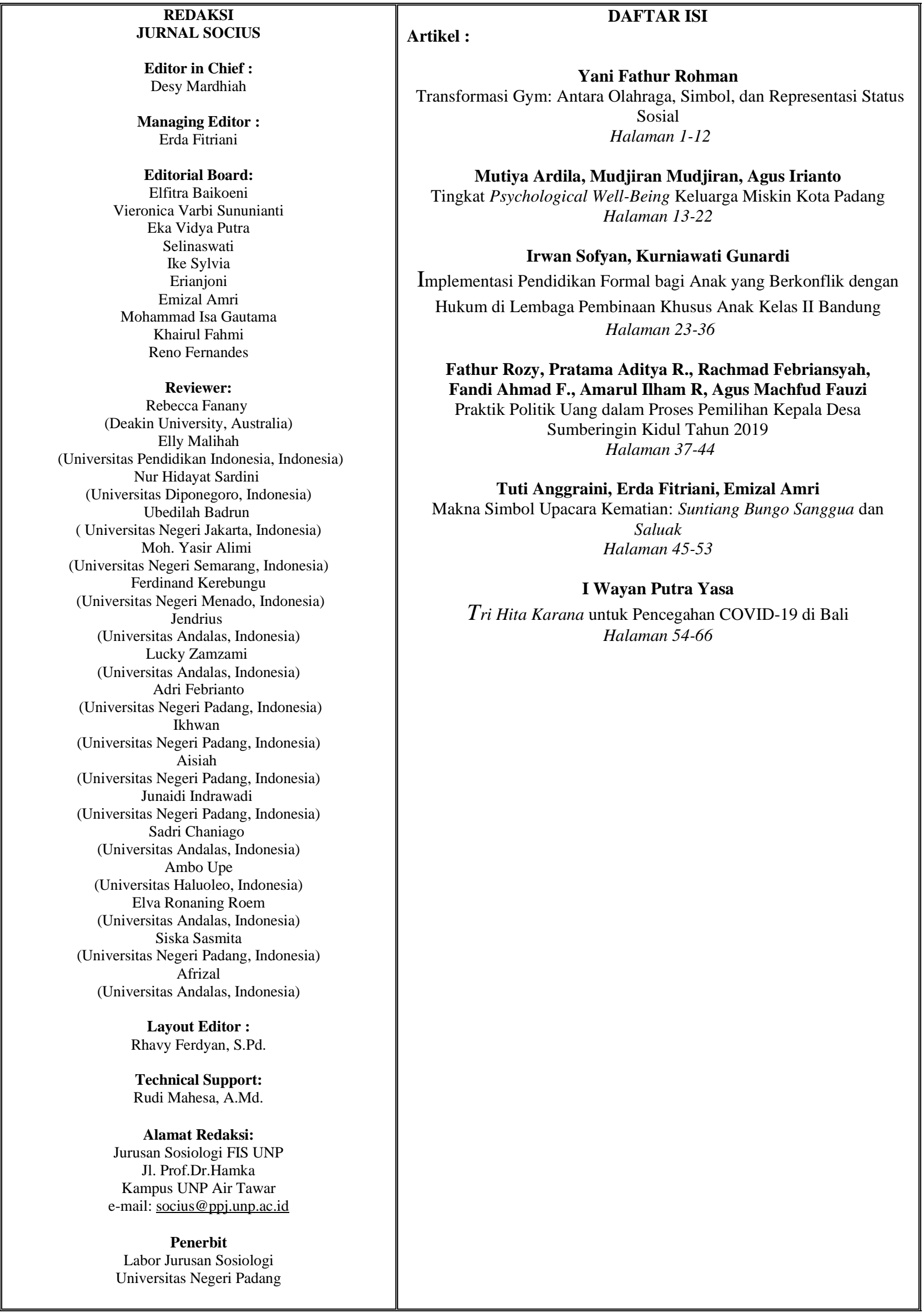




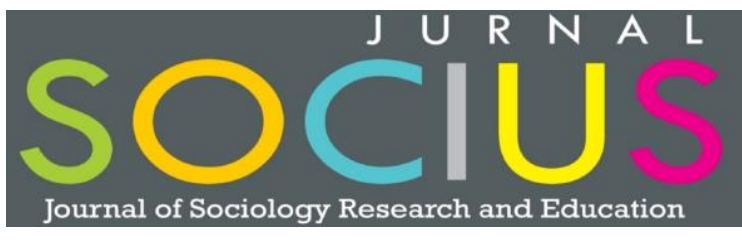

Jurnal Socins: Journal of Sociology Research and Education Vol.7, No.1, Th. 2019

ISSN: Online 2442-8663 - Print 2356-4180

http://socius.ppj.unp.ac.id/index.php/socius

Email: socius@ppj.unp.ac.id

DOI: https://doi.org/10.24036/scs.v7i1.179

\title{
Makna Simbol Upacara Kematian: Suntiang Bungo Sanggua dan Saluak
}

\author{
Tuti Angraini ${ }^{1}$, Erda Fitriani $^{2}$, Emizal Amri $^{3}$ \\ ${ }^{1}$ SMAN 1 Siantan Timur Kepulauan Anambas \\ ${ }^{2,3}$ Universitas Negeri Padang
}

E-mail: angraini2t@gmail.com, fitriani_cim@fis.unp.ac.id, emizalamri01@gmail.com

\begin{abstract}
Abstrak
Artikel ini membahas tentang makna simbol pada upacara kematian masyarakat Nagari Salayo Kecamatan Kubung Kabupaten Solok, Sumatera Barat. Masyarakat Minangkabau yang beragama Islam melaksanakan prosesi upacara secara Islam seperti memandikan, mengkafani, menshalatkan dan menguburkan, akan tetapi di dalam pelaksanaan prosesi upacara kematian yang dilaksanakan masyarakat suatu nagari memiliki keunikan tertentu seperti halnya masyarakat Nagari Salayo. Pada saat mayat berada di dalam rumah dipakaikan suntiang bungo sanggua untuk mayat perempuan atau saluak untuk mayat laki-laki di bagian kepala. Simbol yang ada dalam upacara kematian dianalisa dengan teori interpretivisme simbolik oleh Clifford Geertz. Hasil penelitian ini mengungkapkan makna simbol yang ada dalam upacara kematian adalah penghormatan bagi orang yang meninggal, sebagai tanda orang beradat, hubungan kekeluargaan yang erat, dan solidaritas sosial.

Kata Kunci: Makna Simbol, Interpretivisme simbolik, Suntiang bungo sanggua, Saluak, Upacara kematian

\section{Abstract}

This article discusses the significance of the symbol at the death ceremony of the Nagari Salayo people of the District of Solok District, West Sumatra. The Minangkabau community of Islam performs the process of Islamic ceremonies such as bathing, grooming, officiating and burial, but in the execution of the ceremony of death ceremony performed by the community a nation has certain uniqueness as does the Salayo Nagari community. When the body is in the house is put suntiang bungo sanggua for women or saluak for men at the head. The symbolism in the ceremony of death was analyzed by Clifford Geertz's theory of symbolic interpretation. The results of this study revealed that the meaning of the symbols in the ceremony of death is honor for the dead, as a mark of civilization, close family ties, and social solidarity.
\end{abstract}

Keywords: Death ceremony, Interlaced skull, Squat, Symbolic meaning, Symbolic interpretivism

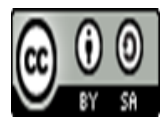

Received: May 13, $2020 \quad$ Revised: June 29, $2020 \quad$ Available Online: June 30, 2020 


\section{Pendahuluan}

Sebagai seorang manusia yang dilahirkan di tengah-tengah suatu kelompok masyarakat, hidup individu ditata oleh aturan adat masyarakatnya. Dalam masyarakat tertentu ada upacara (bahkan ritual) pada masa peralihan, mulai dari kelahiran sampai kematian (Koentjaraningrat, 1998). Pada saat peralihan dari satu tingkat hidup ke tingkat hidup lainnya, biasanya diadakan pesta atau upacara (Keesing, 1981). Upacara- upacara tradisional dalam rangka memperingati masa peralihan satu tingkat hidup individu ke tingkat hidup lainnya dikenal juga dengan istilah upacara masa peralihan (rites de passage) (Koentjaraningrat, 1972). Salah satu dari sekian banyaknya upacara tradisional pada masyarakat Minangkabau yang termasuk dalam rangka upacara masa peralihan yaitu upacara kematian. upacara kematian seperti yang diungkapkan Hertz selalu dilakukan manusia dalam rangka adat istiadat dan struktur sosial dari masyarakat yang terwujud sebagai gagasan kolektif (Koentjaraningrat, 1982).

Dalam banyak kebudayaan di dunia khususnya di Indonesia orang Islam melaksanakan kewajiban atau fardhu kifayah terhadap orang meninggal dengan dilaksanakan prosesi memandikan, mengkafani, menshalatkan, dan menguburkan. Namun dalam prakteknya telah terjadi proses akulturasi dengan kebudayaan yang lama, sebelum masuknya agama Islam seperti yang diungkap dalam beberapa penelitian sebelumnya Yetti Marsanti (2009); Fahmil Pasrah (2017); Abdul Karim (2017); Siti Pheunna Tiara hati (2019).

Pada Masyarakat Minangkabau yang beragama Islam dan terkenal dengan falsafah adat basandi syara', syara' basandi kitabullah, pelaksanaan upacara kematian dilaksanakan secara Islam dan juga secara adat sesuai dengan aturan adat selingkungan nagari. Khususnya masyarakat Nagari Salayo terdapat prosesi upacara kematian yaitu memakaikan atribut yang diletakkan di atas kepala mayat, yaitu berupa suntiang bungo sanggua untuk perempuan, dan saluak untuk laki-laki. Suatu fenomena yang menarik untuk diungkapkan dalam tulisan ini, yaitu suntiang dan saluak merupakan atribut pakaian yang pada kebudayaan Minangkabau secara umum dipakai oleh pengantin laki-laki dan pengantin perempuan sewaktu dilaksanakan upacara perkawinan. Suntiang merupakan hiasan kepala yang menjadi ciri khas dari daerah Minangkabau yang dipakai oleh anak daro (pengantin perempuan). Suntiang menjadi daya tarik tersendiri, karena salah satu hiasan terindah yang tidak dimiliki oleh perempuan sukubangsa lainnya. Bungo sanggua merupakan suntiang khas Nagari Salayo yang merupakan bunga yang menjadi hiasan sanggul pengantin perempuan saat upacara perkawinan maupun untuk mayat perempuan dalam upacara kematian. Sedangkan Saluak merupakan tutup kepala yang dipakai oleh penghulu/ niniak mamak terutama pada upacara adat yang merupakan pakaian adat (Nurdin, 1991).

Fokus dalam penelitian ini adalah tentang makna simbol dari atribut dan aktivitas ketika mayat terbujur di atas rumah. Dalam upacara adat kematian pada masyarakat Nagari Salayo digunakan suntiang bungo sanggua bagi mayat perempuan, saluak bagi mayat lakilaki, dan berbagai atribut seperti kain tabie, kain langik-langik, banta serta sejumlah aktivitas penting. Permasalahan di atas dianalisis dengan mengacu pada teori interpretivisme simbolik oleh Clifford Geertz. Geertz memberikan pengertian kebudayaan memiliki dua elemen, yaitu kebudayaan sebagai sistem kognitif serta sistem makna dan kebudayaan sebagai sistem nilai. Sistem kognitif dan sistem makna ialah representasi pola dari (model of), sedangkan sistem nilai ialah representasi pola bagi (model for) (Geertz, 1999). Teori interpretivisme simbolik memandang manusia sebagai pembawa produk sekaligus subjek dari suatu sistem tindakan 
dan simbol berlaku sebagai sarana komunikasi untuk menyampaikan pengetahuan dan pesanpesan simbol dan pedoman untuk bertindak dan berperilaku. Menurut Geertz, kebudayaan dilihat sebagai sistem yang terkait dari tanda- tanda yang dapat ditafsirkan, dengan kata lain kebudayaan itu merupakan sebuah konteks, dan sesuatu di dalamnya dapat dijelaskan secara mendalam. Geertz mendefinisikan kebudayaan sebagai: (1) suatu sistem keteraturan dari makna dan simbol-simbol tersebut individu-individu mendefinisikan, mengekspresikan perasaan-perasaan dan membuat penilaian; (2) suatu pola makna-makna ditransmisikan secara historis yang terkandung dalam bentuk-bentuk simbol tersebut manusia berkomunikasi, memantapkan, dan mengembangkan pengetahuan mereka mengenai dan bersikap terhadap kehidupannya; (3) suatu perilaku simbolik bagi mengontrol perilaku, sumber-sumber ektrasomatik dari informasi; dan (4) karena kebudayaan adalah suatu sistem simbol, maka proses kebudayaan harus dipahami, diterjemahkan, dan diinterpretasikan (Saifuddin, 2002). Lebih jauh Geertz mengemukakan bahwa teori interpretatif menekankan arti penting partikularitas suatu kebudayaan dan berpendirian bahwa sasaran sentral kajian sosial adalah interpretasi dari praktek-praktek manusia yang bermakna. Simbol menurut Geertz adalah objek, kejadian, bunyi, suara, atau bentuk-bentuk tertulis yang diberi makna oleh manusia (Saifuddin, 2002).

\section{Metode Penelitian}

Penelitian ini dilakukan di Nagari Salayo Kecamatan Kubung Kabupaten Solok selama kurang lebih tiga bulan yaitu dari September sampai November 2016. Dilihat dari segi pendekatannya, penelitian ini termasuk kualitatif dengan tipe etnografi. Pemilihan informan dilakukan secara purposive sampling dengan jumlah informan dua puluh orang. Data dikumpulkan melalui observasi partisipasi dan wawancara mendalam (Subagyo, 2006). Agar data yang diperoleh bisa dipercaya (absah), maka dalam penelitian ini dilakukan triangulasi yaitu triangulasi sumber (Muchtar, 2013). Secara administratif, Salayo merupakan salah satu nagari yang terdapat di kecamatan Kubung, Kabupaten Solok. Terdapat delapan Nagari di Kecamatan Kubung, yaitu Salayo, Koto Baru, Tanjung Bingkung, Panyakalan, Saok Laweh, Gaung, Koto Hilalang, dan Gantung Ciri. Nagari Salayo berada di $64 \mathrm{~km}$ ke arah timur ibu kota Propinsi Sumatera Barat, $25 \mathrm{~km}$ arah Utara Pusat Pemerintahan Kabupaten Solok dan Kantor Wali Nagari berada 0,600 km arah utara dari Pusat Pemerintahan Kecamatan Kubung, serta 2,4 $\mathrm{km}$ arah selatan dari pusat Pemerintahan Kota Solok. Pusat Pemerintahan Nagari Salayo berada di Jalur Lintas Sumatera dengan luas $21,44 \mathrm{~km}$.

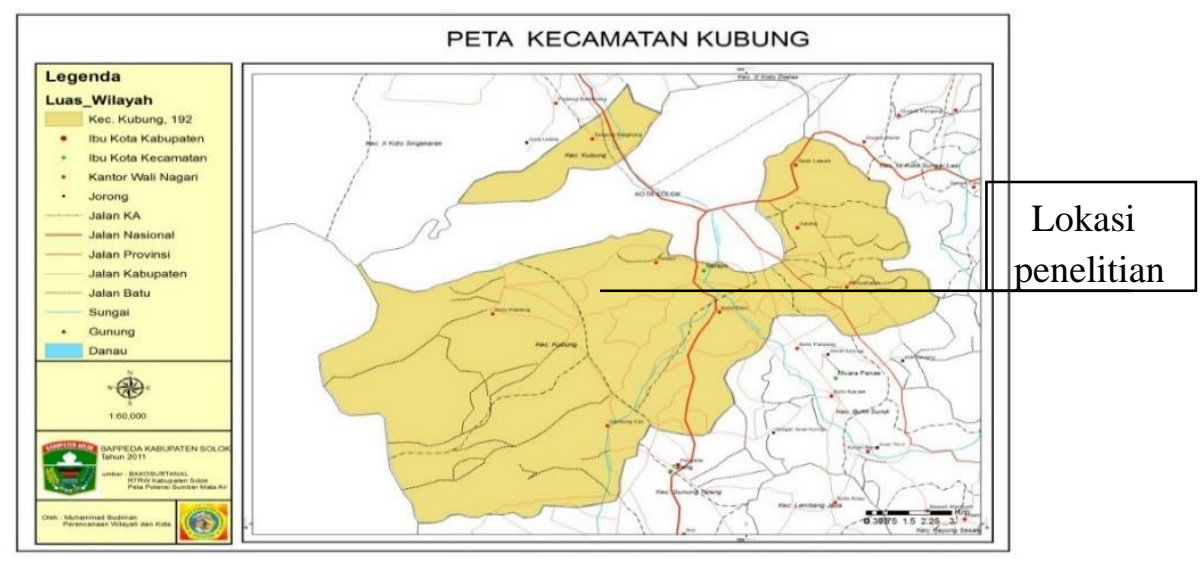

Gambar 1. Peta Kecamatan Kubung

Jurnal Socius: Journal of Sociology Research and Education Vol. 7, No.1, Th. 2020 
Data yang terkumpul dianalisis dengan mengacu pada model analisis interpretatif yang dikembangkan oleh Clifford Geertz, dengan langkah-langkah sebagai berikut: Hermeneutik data, menginterpretasikan data, dan interpretatif direpresentasikan (Endaswara, 2012). Tahap-tahap tersebut merupakan sesuatu yang menjalin satu dengan yang lainnya, berulang dan terus-menerus selama dan sesudah pengumpulan data dalam bentuk yang sejajar, sehingga membentuk konfigurasi yang utuh. Dalam penelitian ini peneliti mencoba memahami aktivitas dan atribut yang digunakan ketika mayat terbujur di atas rumah dari sudut pandang emik, kemudian dari hasil memahami tradisi tersebut dari sudut pandang etik. Peneliti berupaya menemukan makna dan menjelaskannya dengan memanfaatkan teori yang relevan.

\section{Hasil dan Pembahasan}

\section{Makna Simbol dalam Upacara Kematian}

\section{Makna Suntiang Bungo Sangua}

Suntiang merupakan hiasan mahkota perempuan, yang biasa disebut suntiang anak daro (pengantin perempuan) dalam upacara perkawinan. Suntiang pada masyarakat Minangkabau lazimnya digunakan dalam upacara yang bernuansa suka cita, namun pada masyarakat Salayo suntiang juga digunakan saat upacara kematian atau dalam suasana duka. Suntiang yang digunakan masyarakat Salayo dikenal dengan sebutan suntiang bungo sanggua, berbentuk atap rumah gadang sisi depannya dipenuhi dengan bunga, dan bagian belakang hanya terdapat ukiran.

Makna penggunaan suntiang bungo sanggua yang dipahami masyarakat Salayo yaitu dari segi jumlah menandakan status perkawinan seseorang, dan sebagai wujud penghormatan keluarga duka terhadap si mayat. Jika satu saja suntiangnya menandakan bahwa si mayat belum menikah, karena si mayat hanya mendapatkan suntiang dari induak bakonya. Jika si mayat telah bersuami, atau telah menikah maka suntiangnnya berjumlah dua. Di samping dari induak bako, si mayat juga mendapatkan suntiang dari sumandan atau saudara perempuan suaminya.

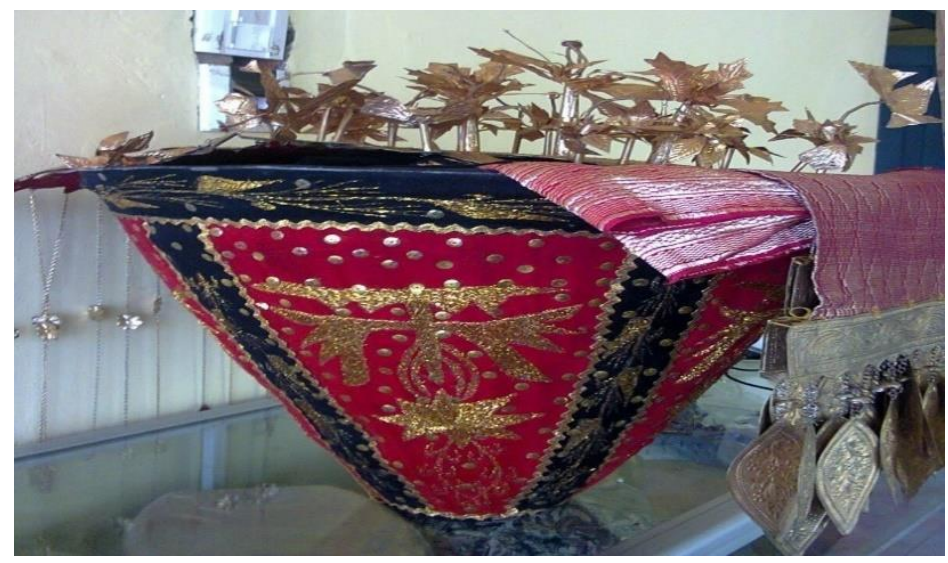

Gambar 2. Tuduang yang berisikan bungo sanggua

Makna suntiang juga sebagai suatu penghormatan bagi si mayat yang datang ke rumah keluarga suaminya saat upacara perkawinan menggunakan suntiang bungo sanggua. Oleh karena itu setelah ia meninggal, maka si mayat juga harus diberi suntiang bungo sanggua. 
Selain suntiang bungo sanggua juga terdapat atribut pakaian pengantin perempuan dalam upacara perkawinan yang disusun rapi di dekat kepala si mayat. Atributnya yaitu baju kuruang itam batabua ameh, salendang balapak, kain saruang balapak, kopiah, galang.

Baju kuruang hitam batabua ameh memiliki makna, bahwa si mayat semasa hidupnya tahan tempa dan terikat oleh suami, adat, dan agama. Salendang balapak memiliki makna beban yang harus dipikul oleh si mayat semasa hidupnya seperti pergi kenduri dan takziah telah terbayar lunas. Kain saruang balapak memiliki makna bahwa si mayat semasa hidupnya memiliki tertib sopan santun. Si mayat semasa hidupnya telah menutup auratnya itulah makna yang terkandung pada simbol kopiah. Si mayat juga bersikap sesuai batasnya, makna itu terkandung dalam simbol galang.

\section{Makna Saluak}

Saluak merupakan penutup kepala penghulu atau marapulai dalam upacara adat yang terbuat dari kain batik atau songket yang ditata sedemikian rupa. Pengganaan saluak untuk almarhum memiliki makna, bahwa almarhum telah memiliki fungsi dalam masyarakat yaitu sebagai mamak atau pemimpin. Oleh karena itu ketika ia dibujurkan di rumah keluarga matrilinealnya harus dipakaikan pakaian kebesarannya seperti saat upacara perkawinan sebagai raja sehari. Selain itu saluak juga memiliki makna penghormatan atas jasa dari almarhum yang telah menjadi pelindung dari anak dan kemenakannya. Selain saluak di dekat kepala almarhum juga diletakkan pakaian pengantin laki-laki seperti sarawa lapang tapak itiak, kain serong, kabek pinggang patah sambilan, baju batabua ameh, karih, dan tungkek. Sarawa lapang tapak itiak merupakan celana berukuran besar yang terbuat dari kain songket yang lazimnya digunakan saat upacara perkawinan. Celana itu juga diberikan ke mayat saat terbujur dan dimaknai oleh masyarakat Salayo sebagai keluasan dan kelapangan ilmu (pengetahuan) serta kearifan yang dimiliki almarhum ketika dia masih hidup. Kain serong merupakan kain sarung songket yang disarungkan di pinggang hingga batas di atas lutut saat upacara perkawinan, dalam upacara kematian hanya diletakkan di dekat mayat. Makna yang terkandung dari kain sarung ini yaitu si mayat memiliki budi pekerti seperti hormat-menghormati. Kabek pinggang patah sambilan merupakan ikat pinggang yang terbuat dari kain tenun berwarna hitam dengan motif garis-garis, dan bewarna emas. Ikat pinggang ini dimaknai oleh masyarakat Salayo, bahwa si mayat merupakan tempat bergantung bagi anak dan kemenakannya. Baju batabue ameh merupakan jas kantor berwarna hitam yang diberi taburan biasa digunakan sebagai atribut tambahan ketika upacara perkawinan. Dalam upacara kematian keris ini memiliki makna kekuasaan si mayat semasa hidupnya sebagai mamak atau pemimpin dari anak dan kemenakannya, yang digunakan bukan untuk membunuh melainkan untuk melindungi. Tungkek merupakan tongkat yang berukiran di pegangan (hulu)nya memiliki makna si mayat sebagai mamak mampu menopang dirinya di samping kewajibannya melindungi anak dan kemenakannya, serta sako dan pusako. Atribut yang diberikan ke mayat laki-laki menunjukkan identitas dari si mayat yaitu berjenis kelamin laki-laki dan merupakan seorang mamak di keluarga matrilinealnya, dan pelindung anak kemenakannya. Identitas merupakan pengenalan atau pengakuan terhadap seseorang sebagai termasuk dalam sesuatu golongan yang dilakukan berdasarkan atas serangkaian ciri-cirinya yang merupakan satu kesatuan yang bulat dan menyeluruh, yang menandainya sebagai termasuk dalam golongan tersebut (Suparlan, 2005). 


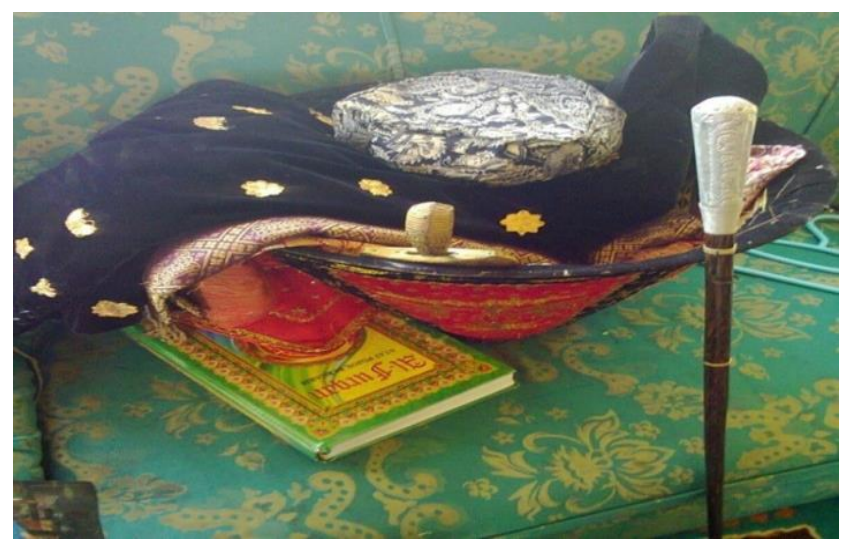

\section{Makna kain tabie}

\section{Gambar 2. Tuduang yang berisikan saluak}

Kain tabie merupakan kain jahitan yang lebarnya dapat menutupi bagian dinding dalam rumah (ruangan mayat terbujur) dari loteng sampai ke lantai, terbuat dasar dari kain perca-perca berwana-warni. Tabie ini memiliki makna baik dari warnanya, bahan maupun dari bentuknya yang dipahami oleh masyarakat Nagari Salayo. Makna kain tabie dari bahan yang tidak mahal melambangkan bahwa si mayat tidak pemboros semasa hidupnya. Warna kain tabie kuning maknanya si mayat semasa hidupnya bersikap adil dan tidak berpihak. Warna merah maknanya keberanian yang di masa hidupnya untuk menyatakan kebenaran, sementara hitam memiliki makna bertanggung jawab atas manik-manik emas yang biasanya dipakai oleh marapulai. Dalam upacara kematian baju ini hanya diletakkan dengan atribut yang lain di dekat si mayat. Adapun makna dari baju ini, yaitu si mayat di masa hidupnya tidak kaya karena harta kaumnya, melainkan karena harta pencahariannya. Karih merupakan senjata yang dimiliki oleh seorang laki-laki, yang bermakna keberanian, dan putih maknanya menegaskan bahwa yang bersangkutan itu bersih dan suci. Tabie terbuat dari kain perca-perca memiliki makna bahwa upacara kematian itu dihadiri segenap karib kerabat. Jumbai- jumbai yang terdapat pada kain tabie memiliki makna, bahwa orang yang duduk di atas rumah yang hadir saat upacara kematian tersebut sama derajatnya.

\section{Makna Kain langik-langik}

Kain langik-langik merupakan kain lebar empat persegi di sekeliling pinggirnya digantungkan jurai-jurai, yang dipasang di langit-langit rumah. Kain langik-langik terbuat dari kain beludru berwarna merah yang disulam dengan benang emas bermotif tumbuhtumbuhan. Langik-langik di pasang di rumah, maknanya pelindung orang yang duduk di bawahnya. Kain berukuran lebar memiliki makna upacara kematian dihadiri oleh orang-orang yang ada hubungan dengan si mayat atau keluarga duka. Langik-langik empat persegi memiliki makna sanak keluarga yang datang dari empat penjuru mata angin.

Berdasarkan jumlahnya langik- langik memiliki makna besar atau kecilnya upacara kematian. Dua kain langik-langik yang dipasang menandakan upacara kematian kecil, dan saat upacara mangaji keluarga duka harus menyemblih kambing. Tiga kain langik-langik memiliki makna upacara kematian menengah yang diharuskan menyemblih seekor sapi. Kemudian jika kain langik- langik sepenuh rumah memiliki makna upacara kematian besar yang diharuskan menyemblih kerbau.

Dari segi jumlah pemasangannya, kain langik-langik memperlihatkan adanya stratifikasi sosial. Semakin kaya atau berkuasa seseorang maka semakin besar pula upacara 
kematian yang dilaksanakan karena berdasarkan kemampuan keluarga duka untuk membiayai upacara kematian. Upacara yang dilaksanakan berdasarkan kemampuan dari keluarga duka, seperti orang biasa yang hanya mampu membeli seekor kambing berbeda dengan upacara kematian saat seorang penghulu yang meninggal harus menyembelih seekor kerbau. Kemampuan itu akan tergambar dari jumlah kain langik-langik yang dipasang di atas rumah.

\section{Makna Banta}

Banta (bukan bantal) merupakan bangunan kerangka katu empat persegi dengan tinggi 1,5 meter dan lebar 0,5 meter yang ditutup dengan lapiak banta (kain beludru berwarna merah yang disulam dengan benang emas motif tumbuh-tumbuhan). Dalam upacara kematian yang dipakai hanya lapiak banta yang digunakan untuk menutupi lemari yang terdapat ujung di ujung rumah. Banta merupakan pakaian rumah yang fungsinya tempat bersandar penghulu atau malin saat upacara kematian. Makna dari banta ini yaitu sandaran yang kokoh yang tidak goyah ke kanan dan ke kiri. Pemimpin yang adil bagi anak dan kemenakan.

Selain atribut di atas, juga ada tambahan atribut dalam upacara kematian besar atau kematian seorang penghulu yaitu berupa kain tijak-tijak, marawa, payuang panji, dan kain barangkok. Kain tijak-tijak merupakan kain putih yang dibentangkan di tangga menuju pintu masuk ke rumah duka (keset). Kain ini memiliki makna pembersih segala kesalahan si mayat terhadap si pelayat yang naik ke rumah duka. Marawa merupakan bendera meruncing berwarna merah, hitam, dan kuning. Ujung kayu penyangganya melengkung, dan dipuncaknya digantungkan umbul-umbul. Marawa ini memiliki makna yang ditafsirkan oleh masyarakat Salayo sebagai bendera kebesaran niniak mamak yang merupakan tempat bergantung dan berlindung bagi anak kemenakannya. Payuang panji merupakan payung berukuran besar bewarna kuning dan pegangannya terbuat dari kayu. Payung ini memiliki makna si mayat merupakan tempat berlindung anak kemanakannya. Kain barangkok merupakan dua kain berukuran lebar berwarna merah dan hitam yang disatukan, tiap ujungnya diberi renda emas. Dalam upacara kematian, kain ini disandangkan kepada orang ampek jiniah dan bajianih. Adapun makna kain barangkok ini adalah segala permasalahan adat yang seharusnya ditanggung oleh si mayat di serahkan ke pemimpin dari kaum yang lain untuk sementara sampai melekatkan gelar ke pemimpin yang baru.

Penggunaan atribut tambahan ini memperlihatkan adanya stratifikasi sosial, tolak ukur terbentuknya adalah kekuasaan. Semakin berkuasa seseorang semakin besar pula upacara kematiannya dan ada pula atribut yang membedakannya dengan masyarakat biasa. Dalam stratifikasi sosial ini terlihat perbedaan-perbedaan yang jelas dalam hal hak, penghasilan, pembatasan, dan kewajiban. Hak para anggota kelompok yang dinilai lebih rendah akan cenderung lebih sedikit daripada hak para anggota kelompok yang dinilai lebih tinggi. Di samping itu, ada kecenderungan bahwa mereka tidak mendapat penghargaan yang sama, dan pembatasan serta kewajiban mereka kemungkinan besar sedikit lebih berat, meskipun para anggota kelompok yang dinilai tinggi juga memiliki pembatasan dan kewajiban yang khas yang harus ditaati.

\section{Makna Induak Bako membawa kain batuduang}

Aktivitas membawa kain batuduang Kain batudung merupakan istilah untuk pakaian pengantin ketika upacara perkawinan dibawa oleh induak bako dengan wadah tuduang. Makna induak bako membawa kain batuduang ini adalah hubungan antara pihak induak bako, anak pisang dan sumandan tidak habis begitu saja meskipun salah satunya sudah 
meninggal. Membawa kain batudung memperlihatkan adanya unsur memperkuat solidaritas kekeluargaan, yaitu memberi penghormatan terakhir kepada si mayat. Dari penjelasan di atas peneliti melihat adanya unsur yang memperkuat solidaritas kekeluargaan dalam upacara kematian. Solidaritas kekeluargaan merupakan kekuatan persatuan internal dari suatu kelompok atau keluarga. Solidaritas kekeluargaan dan kehidupan bermasyarakat itu sangat erat hubungannya dan akan bertambah kuat lagi apabila seseorang menghayati peranannya (role of expectation). Peranan ini telah dipenuhi bila seseorang telah memberi dan menerima bantuan serta memahami cara membangun dan membina hubungan tetap dan harmonis antara dirinya dengan orang lain. Solidaritas ini nyata pada waktu upacara perkawinan dan kematian. Pada saat upacara itu, seluruh kaum kerabat di dalam dan di desa sekeliling akan berkumpul sebagai satu unit solidaritas kekeluargaan. Seseorang akan memberi maupun menerima bantuan kepada dan dari orang yang sekindred sesuai dengan taraf keberadaan (kekayaan).

\section{Makna membawa kain kapan dan memberi daun sereh}

Membawa kain kafan ketika ada yang meninggal merupakan tugas dari sumandan jika salah satu keluarga inti dari suaminya meninggal ataupun salah satu keluarga inti dari istri saudara laki- lakinya. Membawa kain kafan ini memiliki makna rasa kepedulian terhadap keluarga yang mendapatkan musibah. Membawa kain kafan juga memperlihatkan solidaritas kekeluargaan dengan membantu sanak keluarga yag mendapat musibah, dan juga merupakan identitas dari pelayat yang datang merupakan sumandan.

Manyirih merupakan kegiatan memberi sirih yang dilakukan oleh seorang istri kepada kerabat perempuan dari suaminya saat ada kerabat jauh (matrilineal) dari suaminya meninggal. Manyiriah memiliki makna si penyirih bersuami dengan salah satu kerabat lakilaki orang yang disirihinya atau si penyirih merupakan sumandan. Melalui aktivitas ini dapat diketahui indetitas pelayat yang datang memiliki hubungan kekerabatan dengan si mayat dan keluarga duka yaitu sebagai seorang sumandan.

\section{Kesimpulan}

Dalam upacara kematian di Nagari Selayo terdapat berbagai simbol yang memiliki makna bagi masyarakat pemilik kebudayaan. Makna menurut masyarakat Salayo (emik) yang ditarik berdasarkan hermeneutik data, masyarakat menafsirkan keseluruhan simbol dalam upacara kematian memiliki makna. Makna dari Simbol suntiang bungo sanggua dan saluak sebagai penghormatan untuk si mayat. Simbol lain berupa atribut rumah yang terdiri dari kain tabie, kain langik-langik, banta, marawa, dan payuang panji memiliki makna bahwa penyelenggara upacara kematian tando urang baradaik atau tanda orang beradat. Selain itu aktivitas induak bako membawa kain batuduang memiliki makna hubungan kekeluargaan tidak akan terputus meskipun salah satunya sudah meninggal. Makna etik yang ditarik berdasarkan makna emik (interpretative direpresentasikan) adalah adanya stratifikasi sosial, menujukkan identitas serta memperkuat solidaritas kekeluargaan. 


\section{Daftar Pustaka}

Endaswara, S. (2012). Metodologi Penelitian Kebudayaan. Yogyakarta: Gajah Mada University Press.

Geertz, C. (1999). After the Fact: Dua Negeri, Empat Dasawarsa, Satu Antropologi. Yogyakarta: LKIS.

Keesing, R. M. (1981). Antropologi Budaya. Jakarta: Rosda Karya.

Koentjaraningrat, K. (1972). Beberapa Pokok Antropologi Sosial. Jakarta: Dian Rakyat.

Koentjaraningrat, K. (1982). Ritus Peralihan di Indonesia. Jakarta: Balai Pustaka.

Koentjaraningrat, K. (1998). Pengantar Antropologi II: Pokok-Pokok Etnografi. Jakarta: Rineka Cipta.

Muchtar, M. (2013). Metode Praktis Penelitian Deskriptif Kualitatif. Jakarta: Referensi (GP Press).

Nurdin, P. (1991). Pakaian Adat Tradisional Daerah Bengk. Jakarta: Dapertemen Pendidikan dan Kebudayaa.

Saifuddin, A. F. (2002). Antropologi Kontemporer. Jakarta: Kencana Media Group.

Subagyo, J. (2006). Metode Penelitian dalam Teori dan Praktek. Jakarta: Rineka Cipta.

Suparlan, P. (2005). Suku Bangsa dan Hubungan Antar Sukubangsa. Jakarta: Yayasan Pengembangan Kajian Ilmu Kepolisian (PKIK) Press. 